Article

\title{
Isolation, Evaluation, and Identification of Angiotensin I-Converting Enzyme Inhibitory Peptides from Game Meat
}

\author{
Shiro Takeda ${ }^{1,2,3, *(D)}$, Sakurako Kaneko ${ }^{1}$, Kazuyuki Sogawa ${ }^{4}$, Abdulatef M Ahhmed ${ }^{5}$, \\ Hirofumi Enomoto ${ }^{6,7}$ (D), Shinpei Kawarai 1,2,3, Kensuke Taira 1,2,3, Wataru Mizunoya ${ }^{1,2,3}$, \\ Masato Minami ${ }^{1,2,3}$ and Ryoichi Sakata ${ }^{1,8}$ \\ 1 Graduate School of Veterinary Science, Azabu University, Sagamihara 252-5201, Japan; \\ s_kaneko@jlia.jp (S.K.); kawarai@azabu-u.ac.jp (S.K.); taira@azabu-u.ac.jp (K.T.); \\ mizunoya@azabu-u.ac.jp (W.M.); minami@azabu-u.ac.jp (M.M.); sakata@azabu-u.ac.jp (R.S.) \\ 2 School of Veterinary Medicine, Azabu University, Sagamihara 252-5201, Japan \\ 3 Center for Human and Animal Symbiosis Science, Azabu University, Sagamihara 252-5201, Japan \\ 4 School of Life and Environmental Science, Azabu University, Sagamihara 252-5201, Japan; \\ sogawa@azabu-u.ac.jp \\ 5 Chemical and Metallurgical Engineering Faculty, Yildiz Technical University, Istanbul 34220, Turkey; \\ latef.ml@gmail.com \\ 6 School of Science and Engineering, Teikyo University, Utsunomiya 320-8551, Japan; \\ enomoto@nasu.bio.teikyo-u.ac.jp \\ 7 Advanced Instrumental Analysis Center, Teikyo University, Utsunomiya 320-8551, Japan \\ 8 Japan Society for Meat Science and Technology, Ebisu 150-0013, Japan \\ * Correspondence: s-takeda@azabu-u.ac.jp; Tel.: +81-42-850-2450
}

Received: 9 August 2020; Accepted: 19 August 2020; Published: 25 August 2020

check for updates

\begin{abstract}
Game meat has been underutilized, while it offers the potential to diversify not only the human diet but also increase food production and the nutritional value of meat products. This study aimed to determine the angiotensin I-converting enzyme (ACE) inhibitory activities of the digested game meats (venison and boar meat) compared with those of livestock meats (beef and pork). Through the sodium dodecyl sulfate polyacrylamide gel electrophoresis and size chromatography results, we found that the digested products from each meat had different molecular weights. The ACE inhibitory ratio in all tested samples had gradually increased following by the enzyme treatments. ACE inhibitory ratios and the half maximal inhibitory concentration values indicated that digested venison was the most potent inhibitor of ACE activity, followed by the digested boar meat. The level of anserine in digested venison was higher than that in the other meats, but the carnosine level was lower. Through fractionations and liquid chromatography-tandem mass spectrometry analysis, five ACE inhibitory peptides were identified from the digested venison. Of these peptides, Isoleucine-LysineGlutamic Acid-Valine-Threonine-Glutamic Acid-Arginine (IKEVTER) demonstrated the highest ACE inhibitory activity. Therefore, the game meat is food that is believed potentially to offer high bioactivities, particularly antihypertensive forces.
\end{abstract}

Keywords: venison; angiotensin I-converting enzyme (ACE) inhibitory activity; game meat; bioactive peptide; boar meat; gastrointestinal digestion

\section{Introduction}

Meat is recognized as having high nutritional value; it is a good source of protein and also contains group B vitamins, minerals, and trace elements. The worldwide demand for meat continues to rise, 
particularly for pork, beef, and chicken. Game meat, known as meat from wild animals, is thought to have health benefits, including low fat and low cholesterol [1]. Some reports have shown high levels of polyunsaturated fatty acids, including essential fatty acids omega- 3 and omega- 6 , in game meat $[2,3]$. In particular, the omega- 3 acids $\alpha$-linolenic, eicosapentaenoic acid, and docosahexaenoic acid, which might have beneficial effects on consumer health, are present in game meat [4]. However, game meat is currently underutilized, even though it offers the potential to diversify the human diet and increase food production. Venison, one of the game meats, is rich in proteins and primary essential minerals, with a low subcutaneous and infiltrated fat content $[1,5,6]$. In recent years, there has been an increasing interest in the farming of deer for meat products [7]. Moreover, the meat of the reindeer, which also belongs to the Cervidae family and has a red-colored raw muscle tissue, is also believed to be with low fat and cholesterol, and with high vitamin B12, minerals, and trace elements [8-11]. Thus, it is important to experimentally assess the health potential of game meat, including venison, consumed as food.

Great attention has been given to the reduction of risk factors for hypertension or high blood pressure, a common, major cardiovascular disease that affects a wide range of people. This disease primarily occurs due to the lifestyle-related habits and gene sets of an individual, and chemical-based medications have been a general method for its control. However, reports of side-effects of antihypertension medications are so common that many scientists believe that nutritional and therapeutic approaches are better. To that aim, the use of functional foods that are rich in bioactive peptides, also termed nutraceuticals, may be considered as substitutes for many chemical medications. Some low-molecular-weight substances in meat are known to have beneficial bioactivities for human health [12-14]. These substances have been found to be released from meat and meat products using in vitro gastrointestinal digestion systems [15-17]. Meat-derived peptides have an angiotensin I-converting enzyme (ACE) inhibitory functions [18]. ACE plays an important role in the regulation of blood pressure in humans. Thus, the inhibition of ACE is assumed to improve hypertension [19]. Although the bioactivities of game meat or their by-products were reported for their iron-binding activity, antioxidant activity, and neuroprotective activity [20-23], to the best of our knowledge, few studies have investigated the ACE inhibitory activities of game meat and then compared these activities in different animal species.

The aims of the present study were to isolate, identify, and evaluate the inhibitory activity of ACE from game meat. The analyses were carried out for pork, wild boar, beef, and venison. The meat products were heated and treated by in vitro gastrointestinal digestion, mimicking the process of digestion in the human body. Their digestibility and their ACE inhibitory activities were then assayed. Active substances were investigated in samples that demonstrated the highest ACE inhibitory activity.

\section{Materials and Methods}

\subsection{Materials}

The edible round muscle meats from wild deer (Cervus nippon) were obtained from the Komoro City Government of Nagano Prefecture in Japan. Also, the edible round muscle meats of wild boar (Sus scrofa leucomystax) were obtained from the hunting association in Tottori Prefecture in Japan. Both game meat types and their products are available throughout those hunting areas for commercial use and personal consumption. Samples were prepared from three individual wild deer and wild boar. For comparison, three round cuts of beef and pork each were purchased from different local markets in Sagamihara, Kanagawa, Japan. To maintain sample quality, they were stored at $-20^{\circ} \mathrm{C}$ until use and thawed to $4{ }^{\circ} \mathrm{C}$ overnight prior to examination.

\subsection{Preparation of Gastrointestinal Digestions of the Tested Meat In Vitro}

Gastrointestinal digestion was performed according to the method previously reported, with some modifications $[16,17]$. It was assumed the meats were first cooked, then digested by gastrointestinal 
enzymes after consumption. In order to isolate meat tissues, fatty tissues were first removed with a knife; then, the red meat was minced and homogenized with water $(1: 2 \mathrm{w} / \mathrm{v})$ and heated to $70{ }^{\circ} \mathrm{C}$ for $30 \mathrm{~min}$ (untreated group). Then, the $\mathrm{pH}$ was adjusted to 1.8 with $\mathrm{HCl}$, and pepsin (from porcine stomach mucosa, Nakarai Tesque, Kyoto, Japan) was added at a rate (1:1000) (enzyme:protein) and incubated at $37^{\circ} \mathrm{C}$ for $2 \mathrm{~h}$. Afterward, to inactivate the pepsin in the pepsin-treated homogenate (pep group), the $\mathrm{pH}$ was adjusted to 6.8 with $\mathrm{NaOH}$ and the homogenate was boiled for $10 \mathrm{~min}$. Trypsin and pancreatin (both from porcine pancreas, Nakarai Tesque, Kyoto, Japan) were added to the pep group homogenate at the same concentration as that for pepsin and incubated at $37^{\circ} \mathrm{C}$ for $2 \mathrm{~h}$. Subsequently, the homogenate was boiled for $10 \mathrm{~min}$ to inactive the added trypsin and pancreatin (pep/try/pan group). The homogenate was centrifuged at $6000 \times \mathrm{g}$ for $10 \mathrm{~min}$ at $4{ }^{\circ} \mathrm{C}$. Finally, the supernatant was passed through No. 5 filter paper (Toyo Rosi Kaisha, Tokyo, Japan), collected, and stored at $-80^{\circ} \mathrm{C}$ until further use.

\subsection{Analysis of the Products of In Vitro Meat Digestion}

To determine products of digestion in the pep and pep/try/pan groups, peptides in the samples were measured by a previously reported method, with slight modifications [20]. Briefly, the $o$-phthaldialdehyde (OPA) (Nakarai Tesque) reagent was prepared by dissolving $40 \mathrm{mg}$ of OPA in $1 \mathrm{~mL}$ of methanol; it was then mixed with $25 \mathrm{~mL}$ of $100 \mathrm{mM}$ sodium tetraborate buffer, $2.5 \mathrm{~mL}$ of $20 \%$ sodium dodecyl sulfate, and $100 \mu \mathrm{L}$ of $\beta$-mercaptoethanol. The volume was adjusted to $50 \mathrm{~mL}$ by adding distilled water. Twenty microliters of homogenate was added to $1.5 \mathrm{~mL}$ of OPA reagent and incubated for $2 \mathrm{~min}$ at room temperature. The absorbance was read at $340 \mathrm{~nm}$ using a UV-1800 spectrophotometer (Shimadzu, Kyoto, Japan), with Gly-Leu (Nakarai Tesque) as the standard. To determine the changes in the molecular weight and structure of proteins in the digested samples, sodium dodecyl sulfate-polyacrylamide gel electrophoresis (SDS-PAGE) was performed on $16 \%$ acrylamide gels, which were subsequently stained with Coomassie Brilliant Blue solution (Biorad, CA, USA). In addition, size chromatography was carried out using high-performance liquid chromatography (HPLC) with a JASCO LC-1500 intelligent HPLC system (JASCO, Tokyo, Japan). The sample was injected into a column for size exclusion chromatography (Shodex Asahipak GS-320HQ, Showa Denko, Tokyo, Japan). Elution was performed at $30{ }^{\circ} \mathrm{C}$ using $50 \mathrm{mM}$ ammonium acetate adjusted to $\mathrm{pH} 6.7$ at a flow rate of $1.0 \mathrm{~mL} / \mathrm{min}$. The eluent was monitored at $220 \mathrm{~nm}$ with a UV detector (875UV, JASCO). The following molecular weight (MW) references were subjected to size chromatography analysis: bovine serum albumin (MW: 66,000), cytochrome c (MW: 12,400), aprotinin from bovine lung (MW: 6500), and riboflavin (MW: 376). These reagents were purchased from Fujifilm Wako Pure Chemical (Osaka, Japan).

\subsection{Assay of ACE Inhibitory Activity of the Products of In Vitro Meat Digestion}

The digested samples were centrifuged at $10,000 \times g$ for $15 \mathrm{~min}$, and the supernatants were subjected to an ACE inhibitory assay. ACE inhibitory activity was measured using a previously reported method [24,25]. ACE, a dipeptidyl carboxypeptidase (EC 3.4.15.1) extracted from rabbit lung, was obtained from Sigma Chemical Co. (St. Louis, MO, USA). Hippuryl-L-histidyl-L-leucine (HHL) (Nacalai Tesque) was used as the synthetic substrate. A $40 \mu \mathrm{L}$ aliquot of each sample solution was added to $100 \mu \mathrm{L}$ of borate buffer (containing $0.3 \mathrm{M} \mathrm{NaCl}, 5 \mathrm{mM} \mathrm{HHL}, \mathrm{pH} 8.3$ ) and incubated at $37^{\circ} \mathrm{C}$ for $3 \mathrm{~min}$. Then, $20 \mu \mathrm{L}$ ACE solution $\left(0.1 \mathrm{U} \mathrm{mL}^{-1}\right)$ was added to each sample solution, and the reaction mixture was incubated at $37^{\circ} \mathrm{C}$ for $30 \mathrm{~min}$. After that, the reaction was terminated using $250 \mu \mathrm{L}$ of $1 \mathrm{M} \mathrm{HCl}$, and hippuric acid was extracted by adding $1.5 \mathrm{~mL}$ of ethyl acetate and shaking. Eventually, mixtures were centrifuged at $1750 \times g$ for $10 \mathrm{~min}, 1 \mathrm{~mL}$ of supernatant was transferred into a test tube, and ethyl acetate was eliminated by heat evaporation at $95^{\circ} \mathrm{C}$. The precipitate was re-dissolved in $2 \mathrm{~mL}$ of deionized water and measured spectrophotometrically at $228 \mathrm{~nm}$, using a UV-1800 spectrophotometer (Shimadzu, Kyoto, Japan). For the analysis of samples fractionated by reversed-phase chromatography, the synthetic peptides were assayed using the modified method reported by Cheung, et al. [26]. Briefly, 
$50 \mu \mathrm{L}$ of sample solution, $100 \mu \mathrm{L}$ of the ACE $0.01 \mathrm{U} / \mathrm{mL}$, and $20 \mu \mathrm{L}$ of $25 \mathrm{mM}$ HHL were mixed in a 96-well plate and incubated at $37^{\circ} \mathrm{C}$ for $40 \mathrm{~min}$. Subsequently, $100 \mu \mathrm{L}$ of $1 \mathrm{M} \mathrm{NaOH}, 10 \mu \mathrm{L} 0.2 \% \mathrm{OPA}$, and $15 \mu \mathrm{L} 3.6 \mathrm{M}$ phosphoric acid were added, and the fluorescence of samples was measured using the plate-reader POWERSCAN MX (DS Pharma Biomedical Co., Ltd., Osaka, Japan) at an excitation wavelength of $360 \mathrm{~nm}$ and emission wavelength of $460 \mathrm{~nm}$. The inhibitory activity (\%) was calculated as follows: inhibitory activity $(\%)=((\mathrm{Ac}-\mathrm{As}) /(\mathrm{Ac}-\mathrm{Ab})) \times 100$. Ac is the intensity of the control, as is the intensity of the sample, and $\mathrm{Ab}$ is the intensity of the blank. Data are expressed as the $50 \%$ inhibitory concentration $\left(\mathrm{IC}_{50}\right)$ for each sample.

\subsection{Determination of Imidazole Dipeptides in the Digested Meat Products}

The imidazole dipeptides, anserine and carnosine, were measured by HPLC. Digested meat samples were centrifuged at $7000 \times g$ for $5 \mathrm{~min}$. Then, $0.5 \mathrm{~mL}$ of the supernatant from each sample was ultra-filtered at 15,000 $\times g$ for 20 min (Nanosep 10K OMEGA; Pall Corp., New York, NY, USA) to obtain the under-10-kDa fractions. Each fraction was adjusted to $0.5 \mathrm{~mL}$ and analyzed with the HPLC Agilent SERIES 1100 system (Agilent Technologies Inc., Santa Clara, CA, USA). For the analysis of anserine and carnosine, the tested solution was injected into a reversed-phase column (InertSustain AQ-C18; GL Sciences Inc., Tokyo, Japan). Elution was performed at $30^{\circ} \mathrm{C}$ with $0.2 \mathrm{M}$ ammonium dihydrogenphosphate, $0.1 \mathrm{mM}$ 1-pentanesulfonic acid sodium salt, and $4 \%$ acetonitrile solution and adjusted to $\mathrm{pH} 2.0$ with $\mathrm{HCl}$ at a flow rate of $0.8 \mathrm{~mL} \mathrm{~min}^{-1}$. Anserine and carnosine were detected by measuring the absorbance at $220 \mathrm{~nm}$. A solution containing $5.0 \mathrm{mM} \mathrm{L}$-anserine nitrate (Fujifilm Wako Pure Chemical) and $5.0 \mathrm{mM}$ carnosine ( $\beta$-Alanyl-L-Histidine, Peptide Institute, Inc., Osaka, Japan) was used as the standard.

\subsection{Purification and Identification of ACE Inhibitory Peptides in the Digested Meat}

First, gel filtration chromatography was carried out, which fractionated the digested products of the meat according to their molecular mass. The Sephadex G-25 ${ }^{\circledR}$ superfine gel (GE Healthcare, Uppsala, Sweden) was equilibrated with $0.01 \mathrm{~N} \mathrm{HCl}$ in a $4.5 \times 53 \mathrm{~cm}$ column. Then, the separation was performed, using $0.01 \mathrm{~N} \mathrm{HCl}$ as the eluent at a flow rate of $4.0 \mathrm{~mL} \mathrm{~min}^{-1}$ at room temperature, and fractions were collected every 1.5 min using a Bio-collector AC-5750 (ATTO, Tokyo, Japan). All fractions were lyophilized, dissolved in $1.0 \mathrm{~mL}$ distilled water, and stored at $-80^{\circ} \mathrm{C}$ until the ACE inhibitory activity assay was conducted.

Second, the active fraction from size exclusion chromatography in the ACE inhibitory activity assay was re-fractionated using HPLC with a JASCO LC-1500 intelligent HPLC system. The fractionating conditions followed those of a previously published study, with slight modifications [27]. The sample was injected into a reversed-phase column (InertSustain AQ-C18, 4.6 $\times 250 \mathrm{~mm}$; GL Sciences, Tokyo, Japan). Elution was performed at $30^{\circ} \mathrm{C}$ using a linear gradient mobile phase system, from solvent $\mathrm{A}$ (distilled water containing $0.1 \% v / v$ trifluoroacetic acid) to solvent B (acetonitrile containing $0.1 \% v / v$ trifluoroacetic acid), at a flow rate of $0.5 \mathrm{~mL} / \mathrm{min}$. The gradient program was carried out in $65 \mathrm{~min}$ (solvent B $30 \%$ at $30 \mathrm{~min}$, solvent B $50 \%$ at $60 \mathrm{~min}$, and solvent B $0 \%$ at $65 \mathrm{~min}$ ). The eluent was monitored at $220 \mathrm{~nm}$ with a UV detector (875UV, JASCO) to observe the resultant peaks, and the components of the samples were collected every 2 min using a Bio-collector AC-5750 (ATTO). The fractionated samples were lyophilized, dissolved in $1.0 \mathrm{~mL}$ distilled water, and stored at $-80{ }^{\circ} \mathrm{C}$ until the $\mathrm{ACE}$ inhibitory activity assay. The active fraction was freeze-dried and used for the next analysis.

Third, the active fraction from HPLC in the ACE inhibitory activity assay was used to identify the amino acid sequences of the peptides, following the protocol of a previously reported study [28]. The lyophilized samples were rehydrated in $10-30 \mu \mathrm{L}$ of $25 \mathrm{mM}$ Tris- $\mathrm{HCl} / 20 \% \mathrm{CH}_{3} \mathrm{CN}$ containing $25 \mathrm{ng} / \mathrm{L}$ trypsin (Trypsin Sequence Grade; Roche Diagnostics GmbH, Mannheim, Germany) for 45 min. Following the removal of the unabsorbed solution, the lyophilized samples were incubated in 10-20 $\mu \mathrm{L}$ buffer of $50 \mathrm{mM}$ Tris- $\mathrm{HCl} / 20 \% \mathrm{CH}_{3} \mathrm{CN}$ for $20 \mathrm{~h}$ at $37^{\circ} \mathrm{C}$. The solution containing digested protein fragments was transferred to a substitute tube, and the peptide fragments remaining in the gel were 
extracted in 5\% formic acid $/ 50 \% \mathrm{CH}_{3} \mathrm{CN}$ for $20 \mathrm{~min}$ at room temperature [29]. The peptides were injected into a $0.3 \times 5 \mathrm{~mm}$ L-trap column (Chemicals Evaluation and Research Institute, Saitama, Japan) and a $0.1 \times 50 \mathrm{~mm}$ Monolith analytical column (AMR, Tokyo, Japan) attached to an HPLC system (Nanospace SI-2; Shiseido Fine Chemicals, Tokyo, Japan). The flow rate of the mobile phase was $1 \mu \mathrm{L} \mathrm{min}{ }^{-1}$. The solvent composition of the mobile phase was programmed to change in $35 \mathrm{~min}$ cycles, with varied mixing ratios of solvent $\mathrm{A}\left(2 \% v / v \mathrm{CH}_{3} \mathrm{CN}\right.$ and $\left.0.1 \% v / v \mathrm{HCOOH}\right)$ to solvent $\mathrm{B}$ ( $90 \% v / v \mathrm{CH}_{3} \mathrm{CN}$ and $\left.0.1 \% v / v \mathrm{HCOOH}\right)$. The gradient system of the mobile phase was as follows: $5-50 \%$ solvent B for $20 \mathrm{~min}, 50-95 \%$ solvent B for $1 \mathrm{~min}, 95 \%$ solvent B for $3 \mathrm{~min}, 95-5 \%$ solvent B for $1 \mathrm{~min}$, and $5 \%$ solvent $B$ for $10 \mathrm{~min}$. Purified peptides from HPLC were introduced into an LTQ-XL ion trap mass spectrometer (Thermo Scientific, San Jose, CA, USA) via an attached Pico Tip (New Objective, Woburn, MA, USA). MS and MS/MS peptide spectra were measured in a data-dependent manner. The MASCOT search engine (Matrix Science, London, UK) was used to identify proteins from the mass and tandem mass spectra of the peptides. Peptide mass data were matched by searching the NCBI database using the MASCOT engine. The minimum significant threshold level for the probability-based MASCOT/MOWSE score was set at 5\% [30]. A search of ACE inhibitory peptides was carried out using BIOPEP and the Anti-Hypertensive Inhibiting Peptide Database (AHTPDB) [31].

Peptides were synthesized by Scrum Inc. (Tokyo, Japan). The synthetic peptides were purified using an HPLC column with $98 \%$ purity.

\subsection{Statistical Analyses}

All measurements were conducted in triplicate, with each replicate employing a different individual sample. The data are expressed as the mean \pm standard deviation $(\mathrm{SD}, n=3)$. The results were analyzed by one-way analysis of variance (ANOVA), followed by Tukey's test. A $p$-value of less than 0.05 was defined as statistically significant.

\section{Results and Discussion}

\subsection{Products Released from the Digestion of the Tested Meats}

Several approaches of bioactivity assay have been performed on hydrolysates obtained by enzymatic hydrolysis to determine whether they can detect new peptides in meat products [32]. In the current study, we subjected the tested meats to in vitro gastrointestinal digestion. The peptide concentrations in the untreated, pep, and pep/try/pan groups for all tested meats are shown in Table 1. The untreated group was prepared to yield the water-soluble peptide by cooking. The pep and pep/try/pan groups were obtained for the released peptides, which mainly comprised of aromatic amino acids, and for the released furthermore peptides, respectively. All peptide concentrations in the tested meat samples were significantly elevated in the pep group and further increased in the pep/try/pan group compared to those in the untreated group. For each treatment, there was no difference between the digested meat samples from the different animal species. The water-soluble extracts from cooked pork, boar meat, beef, and venison were subjected to SDS-PAGE (Figure 1a), and their banding patterns for water-soluble proteins (each lane labeled:1) were almost identical. However, boar meat showed a distinctive expression of proteins, with the band at $75 \mathrm{kDa}$ being much larger than that of meat from the other species. In addition, the boar samples displayed a greater number of proteins compared to the others, especially in the range of 36-75 kDa. The pep groups for all tested meats (each lane labeled: 2) were generally similar with respect to their banding patterns, but the intensities of some bands, such as those of the protein bands from $25-37 \mathrm{kDa}$, were different between groups. It was thought that pepsin in some digested meats might interfere to cleave the proteins at aromatic amino acid residues. Proteins in the pep/try/pan group of each meat type (each lane labeled 3) had completely disappeared and had been digested to form components $<20 \mathrm{kDa}$ in weight. To investigate the products of digestion, the water-soluble extracts of the pep and pep/try/pan groups in the pork, boar meat, beef, and venison were subjected to a size chromatography analysis (Figure 1b). 
The signal intensities from the chromatogram of digested groups in each meat type were elevated from 6.5-12 kDa, compared to those observed within the first $10 \mathrm{~min}$ of elution.

Table 1. Peptide concentrations in the products of digested meats.

\begin{tabular}{cccc}
\hline & \multicolumn{3}{c}{ Peptide Concentration (mM) } \\
\cline { 2 - 4 } & Untreated & Pep & Pep/Try/Pan \\
\hline Pork & $22.28 \pm 0.99^{\mathrm{a}}$ & $52.80 \pm 6.65^{\mathrm{b}}$ & $80.10 \pm 5.52^{\mathrm{c}}$ \\
Boar meat & $20.32 \pm 1.36^{\mathrm{a}}$ & $58.03 \pm 6.50^{\mathrm{b}}$ & $78.45 \pm 8.09^{\mathrm{c}}$ \\
Beef & $23.56 \pm 1.83^{\mathrm{a}}$ & $51.62 \pm 1.89^{\mathrm{b}}$ & $78.95 \pm 3.28^{\mathrm{c}}$ \\
Venison & $22.20 \pm 2.00^{\mathrm{a}}$ & $50.56 \pm 2.37^{\mathrm{b}}$ & $75.70 \pm 4.87^{\mathrm{c}}$
\end{tabular}

The mean and standard deviation of three independent experiments are presented. Values with different superscripts indicate a significant difference in each digested group, as determined by one-way ANOVA, followed by Tukey's test $(p<0.05)$.

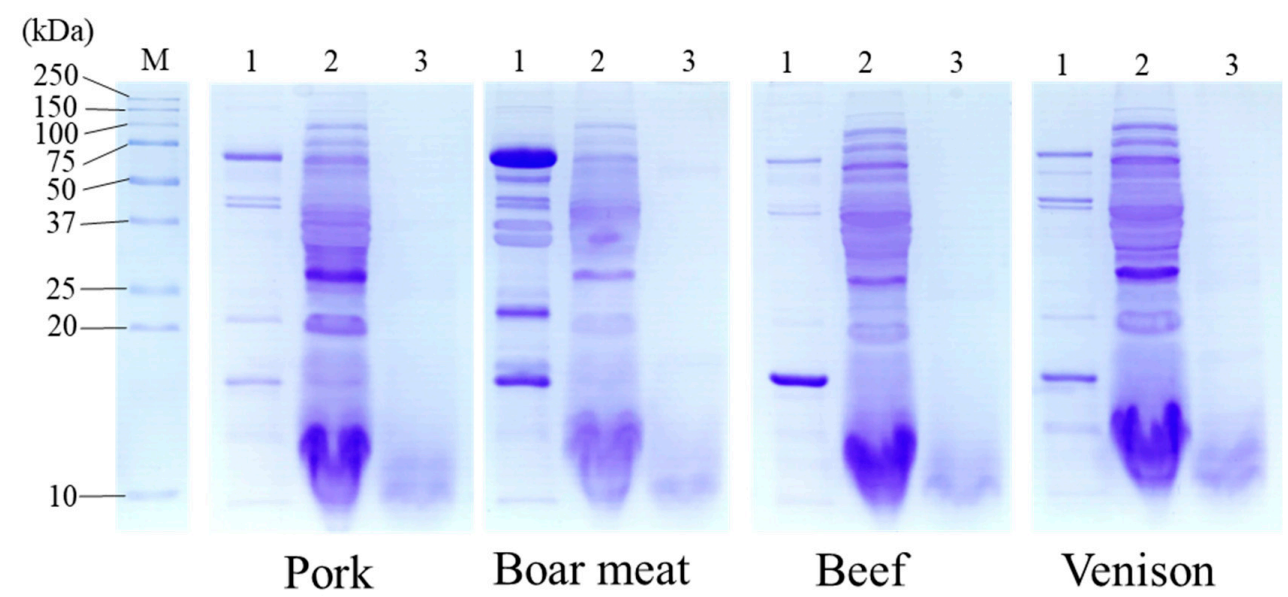

(a)

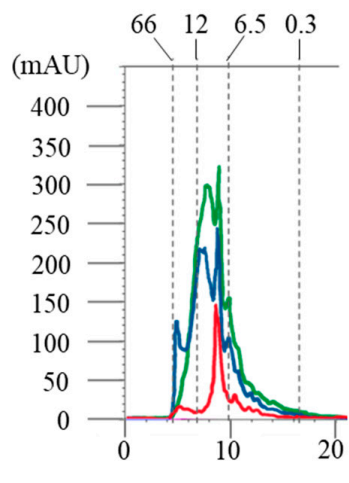

Pork

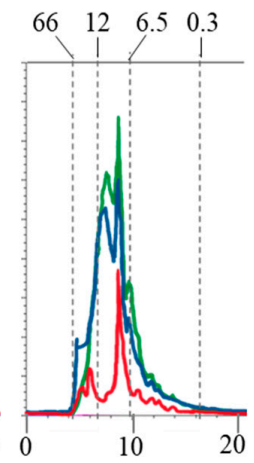

Boar meat

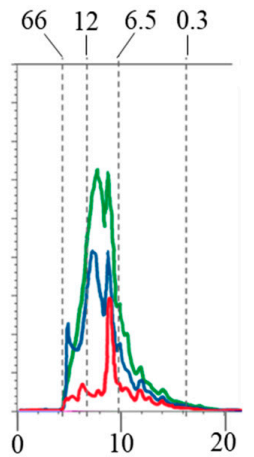

Beef

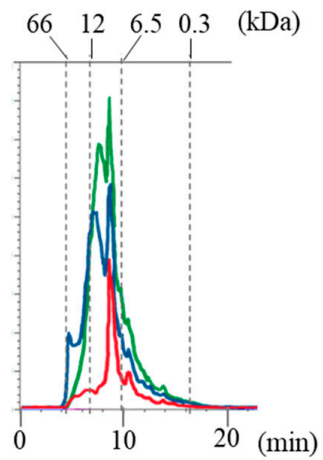

Venison

(b)

Figure 1. Sodium dodecyl sulfate polyacrylamide gel electrophoresis (SDS-PAGE) profile and chromatograms of the digested meat using size exclusion chromatography. (a) SDS-PAGE results of the digested meat. (M) is the lane with the marker. (1), (2), and (3) are the lanes for untreated, pep, and pep/try/pan groups, respectively. (b) Chromatograms of digested meats. The lines in red, blue, and green are the chromatograms of untreated, pep, and pep/try/pan groups, respectively. 
It was previously reported that the percentages of meat protein digested by pepsin and trypsin are similar among farmed species, including pork and beef [33]. We also found that the digestibilities of boar meat and venison, as well as those of pork and beef, in pep and pep/try/pan were almost the same; there were no significant differences in peptide concentrations (Table 1). Moreover, the results obtained through SDS-PAGE in the pep group were consistent with those obtained through size chromatography in the pep and pep/try/pan groups (Figure 1a,b). The peptide profiles of meat protein digested by pepsin and trypsin have been reported to be different among meat species due to a difference in amino acid contents $[33,34]$, as well as due to chemical bonds and forces, such as hydrophobic and disulfide interactions. There might be other extrinsic factors leading to differences in the muscle and muscle protein structures between different tested animal species, such as diet and feed, breeding regime, age, and the physical and social stress of pre-slaughter or hunting. Although the patterns of molecular products released by treatment with pep and/or pep/try/pan appeared to be similar between the different meats, the substances presented in a molecular weight might be different in this study. In effect, the expression levels of those substances were consistent, but the number or type of the amino acids would be diverse, which resulted in differing molecular weights of the substances. Hereby, it is believed that the digested meat products in this study had specific peptide sequences and characteristic bioactivities, including ACE inhibitory activity.

\subsection{ACE Inhibitory Activity and Imidazole Dipeptide Content in the Digested Meat Products}

The ACE inhibition ratios induced by the water-soluble extract and its digestion products are shown in Table 2. The percentage of ACE inhibition in each meat sample was significantly elevated in the pep and pep/try/pan groups compared to that in the untreated group $(p<0.05)$. The highest percentage inhibition for pork and venison was observed in their pep/try/pan groups. Inhibition rates for venison in the pep/try/pan groups were significantly higher than those in the pep group $(p<0.05)$ and significantly higher than those for the other meat samples $(p<0.05)$. Boar meat and beef showed the highest inhibition ratios in their pep groups and the lower inhibition ratios in their pep/try/pen groups, but the difference was not significant. The percentage inhibition of ACE by boar meat in the pep group was significantly higher than that of pork and beef $(p<0.05)$. The pep/try/pan-treated samples were assayed to determine their $\mathrm{IC}_{50}$ value, the concentration of the generated peptides required to reach $50 \%$ inhibition of $\mathrm{ACE}$. The $\mathrm{IC}_{50}$ values of pork, beef, wild boar meat, and venison in the pep/try/pan group were $0.48 \pm 0.07,0.58 \pm 0.12,0.41 \pm 0.10$, and $0.30 \pm 0.09 \mathrm{mM}$, respectively. Notably, the $\mathrm{IC}_{50}$ value for venison treated by pep/try/pan was significantly lower than that of the other digested meats $(p<0.05)$.

Table 2. Angiotensin I-converting enzyme (ACE) inhibitory activities in the digested meat products.

\begin{tabular}{cccc}
\hline \multirow{2}{*}{ Meat Type } & \multicolumn{3}{c}{ ACE Inhibitory Percentage (\%) } \\
\cline { 2 - 4 } & Untreated & Pep & Pep/Try/Pan \\
\hline Pork & $43.71 \pm 5.42^{\mathrm{a}, \mathrm{A}}$ & $64.36 \pm 1.00^{\mathrm{b}, \mathrm{A}}$ & $65.00 \pm 6.43^{\mathrm{b}, \mathrm{A}}$ \\
Boar meat & $44.67 \pm 5.03^{\mathrm{a}}, \mathrm{A}$ & $79.44 \pm 1.70^{\mathrm{b}, \mathrm{B}}$ & $78.04 \pm 2.47^{\mathrm{b}, \mathrm{B}}$ \\
Beef & $47.18 \pm 5.90^{\mathrm{a}} \mathrm{A}$ & $64.15 \pm 2.81^{\mathrm{b}, \mathrm{A}}$ & $63.20 \pm 3.26^{\mathrm{b}, \mathrm{A}}$ \\
Venison & $52.60 \pm 2.89^{\mathrm{a}}, \mathrm{A}$ & $77.29 \pm 5.96^{\mathrm{b}, \mathrm{AB}}$ & $89.38 \pm 5.57^{\mathrm{c}, \mathrm{C}}$ \\
\hline
\end{tabular}

The sample was prepared at a $10 \mathrm{mM}$ peptide concentration for assaying ACE inhibitory activity. The mean and standard deviation of three independent experiments are presented. Different small letters indicate a significant difference in each tested meat group, as determined by one-way ANOVA, followed by Tukey's test $(p<0.05)$. Different large letters indicate a significant difference in each enzyme-digested group, as determined by one-way ANOVA, followed by Tukey's test $(p<0.05)$.

To investigate whether the imidazole dipeptides (anserine and carnosine) of the digested meat products affected the ACE inhibitory activities in this study, their levels were measured in each $\mathrm{pep} / \mathrm{try} / \mathrm{pan}$ group. The concentrations of imidazole dipeptides varied quite remarkably between meat species (Table 3). The anserine levels of the digested beef, boar meat, and venison were significantly 
higher than those of digested pork $(p<0.05)$. In particular, the anserine level of digested venison was significantly higher than that of all the other tested meats $(p<0.05)$. The concentration of anserine in venison was 10-fold higher than that in pork. However, the carnosine levels in the digested pork and beef were significantly higher than those in the digested boar meat and venison $(p<0.05)$, and the level in venison was the lowest among the levels in the tested meats; this result was opposite to that for anserine.

Table 3. Imidazole dipeptide content in the digested meat products.

\begin{tabular}{ccc}
\hline Meat Type & Anserine $(\mu \mathrm{M})$ & Carnosine $(\mu \mathrm{M})$ \\
\hline Pork & $66.67 \pm 1.15^{\mathrm{a}}$ & $2750 \pm 100^{\mathrm{a}}$ \\
Beef & $323.33 \pm 7.02^{\mathrm{b}}$ & $2190 \pm 40^{\mathrm{a}}$ \\
Boar meat & $401.33 \pm 9.45^{\mathrm{c}}$ & $1730 \pm 30^{\mathrm{b}}$ \\
Venison & $668.67 \pm 1.15^{\mathrm{d}}$ & $1040 \pm 10^{\mathrm{c}}$ \\
\hline
\end{tabular}

The mean and standard deviation of three independent experiments are presented. Values with different superscripts indicate a significant difference in a column of anserine or carnosine by one-way ANOVA, followed by Tukey's test $(p<0.05)$.

Previous studies have shown that proteolysis by enzyme digestion could trigger the generation of many bioactive peptides, including ACE inhibitory peptides with low molecular weights [18]. In this study as well, we observed a significant elevation of ACE inhibitory activity in the pep and pep/try/pan groups for all tested meats compared to those of the untreated groups $(p<0.05)$. Jensen et al. reported that the ACE inhibitory activities did not significantly differ between pork and beef, which is consistent with the results in this study [35]. However, several other studies have shown different tendencies: the difference of ACE inhibitory activities between the digested pork and beef was observed. One of the reasons might be that the in vitro digestion was conducted in several different procedures and conditions. The standardized in vitro food digestion protocol was recently published [36]. Thus, it would be expected to be used to prepare the digested meat products in further studies. Meanwhile, boar meat and venison showed higher ACE inhibitory percentages after pep/try/pan digestion than pork and beef, and the $\mathrm{IC}_{50}$ value of venison in the pep/try/pan group was significantly lower than those in the pep/try/pan groups of other digested meats. Livestock meat and game meat differ in physicochemical quality $[1,5]$. In addition, the chemical composition of raw meat also differs between animal species $[5,37]$. Thus, the differences in physicochemical quality between livestock meat and game meat might cause differences in the compositions of digested products and their ACE inhibitory activities. In addition, the ACE inhibitory activities of the game meats including boar meat and venison are potentially higher than those of pork and beef, which might be the cause of their greater in vivo antihypertensive activity.

Imidazole dipeptides, including anserine and carnosine, are known to be bioactive components of meat and demonstrate ACE inhibitory activity $[12,38,39]$. In addition, it was reported that the anserine and carnosine levels were different among meats from various farm animal species; the carnosine levels of pork and beef were clearly higher than those of chicken, sheep, and turkey, but the anserine levels of pork and beef were lower [40,41]. In this study, the levels of carnosine in digested pep/try/pan groups of all tested meats were higher than those of anserine. Although, the carnosine level of venison treated by pep/try/pan was the lowest in the tested meats, the anserine level of venison treated with pep/try/pan was the highest among the tested meats; this result is consistent with the results of ACE inhibitory activity. Thus, anserine is potentially an active substance, however, the other peptide might have contributed to express the high ACE activity in the venison treated with pep/try/pan.

\subsection{Purification and Identification of ACE Inhibitory Peptides in the Digested Venison}

Bioactive peptides, including those with antihypertensive activity, have sequences of 2-30 amino acids [42,43]. They have been identified in a wide variety of foods, including milk; muscle sources, such as beef, chicken, pork; marine sources, but not so extensively in game meat. To investigate the 
peptides derived from digested venison in the pep/try/pan group, which showed the highest ACE inhibitory activity, it was subjected to gel filtration chromatography using a Sephadex G-25 column. The ACE inhibitory activity of each fraction is shown in Figure 2. The results show that the fraction eluted at 34-36 min after the loading of the sample had the greatest ACE inhibitory activity; its $\mathrm{IC}_{50}$ value was the lowest among all tested fractions. This eluted fraction was subjected to reversed-phase chromatography in an HPLC system. The chromatogram obtained for the samples fractionated by HPLC is shown in Figure 3a, then the 24 fractions were assessed for ACE inhibitory activity. As shown in Figure $3 b$, the fraction eluted at $25-27$ min after loading had the greatest ACE inhibitory ratio. The next highest ACE inhibition ratios, in descending order, were observed in fractions obtained at 23-25, 55-57, and 27-29 min.

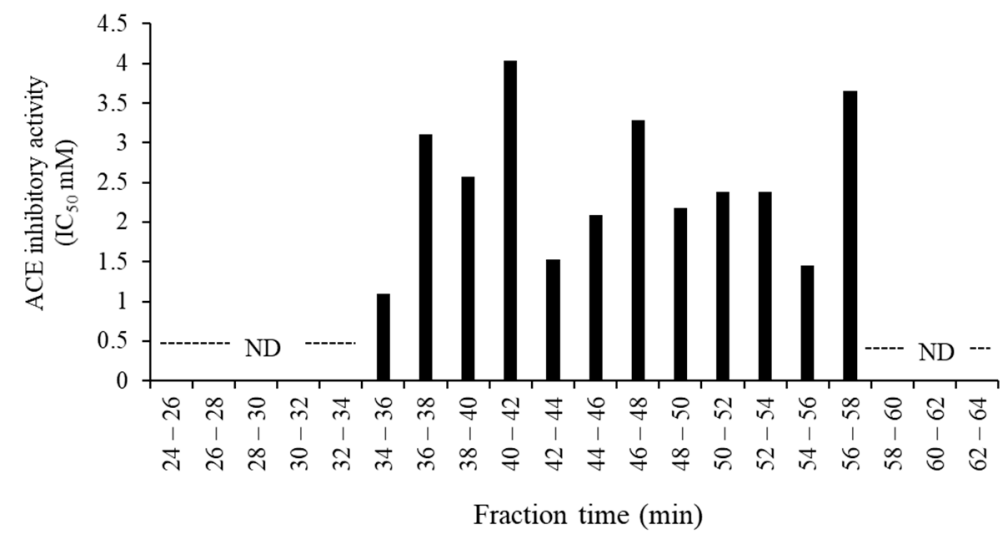

Figure 2. Angiotensin I-converting enzyme (ACE) inhibitory activity of the fractions of digested venison. The venison digested with pepsin, trypsin, and pancreatin was fractionated using gel filtration chromatography. The ACE inhibitory activity in each fraction was assayed. The data were expressed as mean in triplicates. ND in the figure indicates "not detectable".

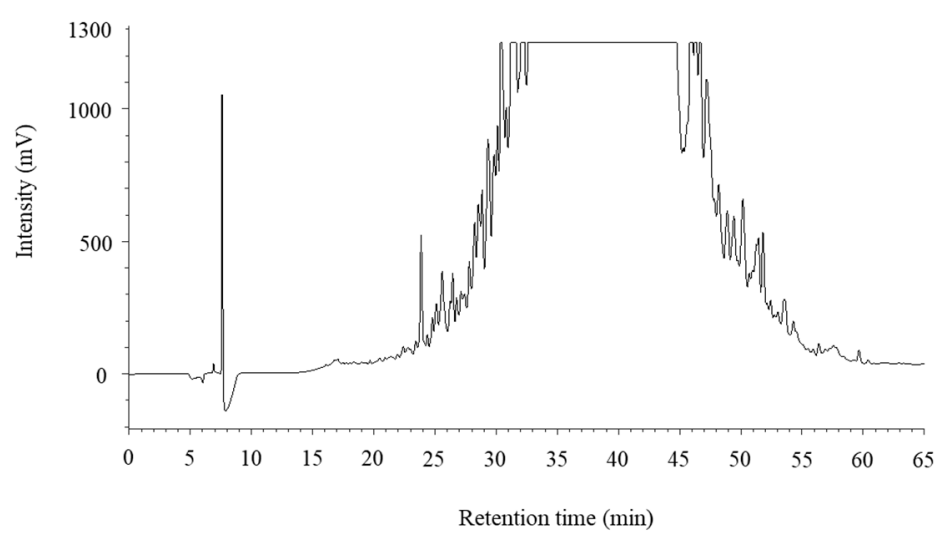

(a)

Figure 3. Cont. 


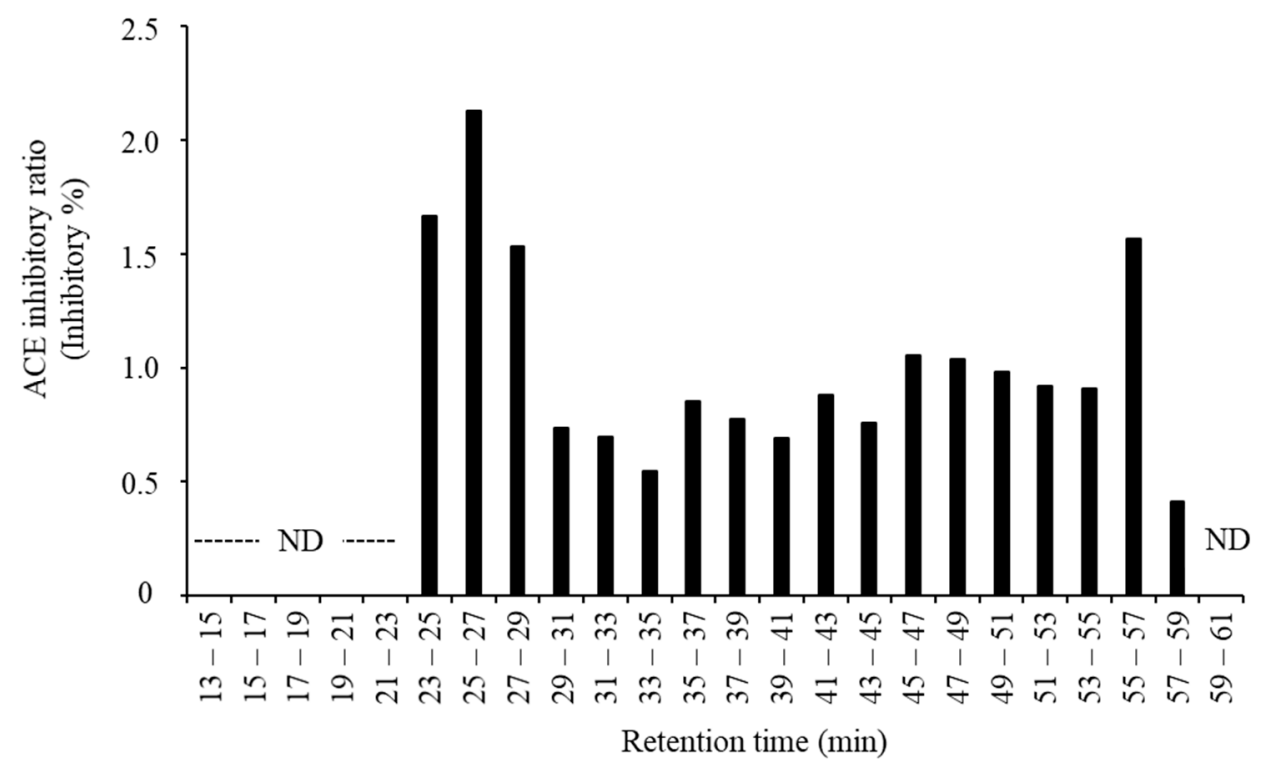

(b)

Figure 3. Chromatogram in reversed-phase HPLC and the angiotensin I-converting enzyme (ACE) inhibitory activity of fraction of the digested venison. (a) Chromatogram in reversed-phase HPLC using the fraction at 34-36 min by gel filtration chromatography. (b) ACE inhibitory activity of the fractions using reversed-phase HPLC. The data are expressed as the means of triplicates. ND in the figure indicates "not detectable".

To identify the source of the ACE inhibitory activities, the most active fraction (eluted at 25-27 $\mathrm{min}$ ) was subjected to LC-MS/MS analysis. According to the results and using a database, five peptides were selected for analysis for amino acid identification and to determine from which proteins they originated (Table 4). In addition, the identified peptides were synthesized, and their ACE inhibitory activities were assayed (Table 4). All the synthesized peptides showed the ACE inhibitory activities, except for the peptide SEIQAALEEAEASLEHEEGK which was derived from myosin-1. IKEVTER is another myosin-1 peptide, which demonstrated great activity for ACE inhibition and could be considered a valuable ACE inhibitory peptide, with an $\mathrm{IC}_{50}$ value of $86.52 \mu \mathrm{g} / \mathrm{mL}$, which was significantly lower than those of the other synthesized peptides. Moreover, this peptide sequence has not yet been observed in the bioactive peptide databases at BIOPEP and AHTPDB.

Table 4. Identified and synthesized peptides from the digested venison and their angiotensin I-converting enzyme (ACE) inhibitory activities.

\begin{tabular}{ccc}
\hline Peptide Sequence & Origin & Ace Inhibitory Activity $\left(\mathrm{IC}_{\mathbf{5 0}}: \boldsymbol{\mu g} / \mathbf{m L}\right)$ \\
\hline VcNYVNWIQQTIAAN & Tropomyosin alpha-3 chain & $358.64 \pm 64.71^{\mathrm{a}}$ \\
mQGTLEDQIISANPLLEAFGNAK & Myosin-1 & $292.83 \pm 38.27^{\mathrm{a}, \mathrm{b}}$ \\
IKEVTER & Myosin-1 & $86.52 \pm 18.84^{\mathrm{c}}$ \\
TEAGATVTVK & Myosin-1 & $208.64 \pm 5.57^{\mathrm{b}}$ \\
SEIQAALEEAEASLEHEEGK & Myosin-1 & $\mathrm{ND}$ \\
\hline
\end{tabular}

The means and standard deviations of three repeated experiments are presented as the results of ACE inhibitory activity. Values with different superscripts indicate a significant difference compared to other values in the column, as determined by one-way ANOVA, followed by Tukey's test $(p<0.05)$. ND indicates "not detectable".

The potent ACE inhibitory peptides are generally short chains of 3-6 amino acids, with a Ser, Leu, or Thr at the C-terminal, which plays an important role in this activity [31]. The ACE inhibitory peptides identified in this study, except for IKEVTER, seem to be of a larger size than those of inhibitory peptides described in previous reports. ACE inhibitory peptides have been previously reported from 
meat and seafood vertebrate specimens, and their $\mathrm{IC}_{50}$ values have been reported [18]. The ACE inhibitory peptides derived from meat do not always include a Ser, Leu, or Thr at the C-terminal. The peptide 'IKEVTER' which had high ACE activity in the present study, also does not consist of those amino acids. Many peptides, with various amino acid sequences, have shown strong ACE inhibitory activity, including ND, TK, GFHI, DFHING, FHG, and GLSDGEWQ, with ACE inhibition $\mathrm{IC}_{50}$ values of $3.9,112,117,64.3,52.9$, and $50.5 \mu \mathrm{g} / \mathrm{mL}$, respectively $[18,44,45]$. Since the $\mathrm{IC}_{50}$ value of the peptide IKEVTER was $86.52 \mu \mathrm{g} / \mathrm{mL}$, its activity was thought to be in an acceptable range for ACE inhibition, compared to those of other reported peptides. Therefore, the IKEVTER peptide is considered a novel ACE inhibitory peptide from the venison treated with pep/try/pan.

\section{Conclusions}

The ACE inhibitory activities were different among the samples digested with pep and/or pep/try/pan in each tested meat species. In particular, venison in the pep/try/pan group demonstrated the highest $\mathrm{ACE}$ inhibition ratio and the lowest $\mathrm{IC}_{50}$ value. The digestibilities of meat tested by pep and pep/try/pan were similar, and there were no significant differences in the peptide levels of different digestion groups. Thus, the components of digested products might be distinctive for each tested meat species. Although the carnosine level in venison in the pep/try/pan group was lowest among the tested meats, the anserine level was the highest. Moreover, the peptide IKEVTER was identified as a novel ACE inhibitory active substance in the venison treated by pep/try/pan. Based on these results, the present study provides an insight into the release of antihypertensive peptides in game meat, using the peptic digestion process. In particular, our findings suggest that venison has ACE inhibitory activities. Therefore, venison can be described as a meat with high bioactivity as well as with low fat, low cholesterol, and high polyunsaturated fatty acids. Further studies are necessary, using a live animal model, on the bioavailability of the novel peptide identified from pep/try/pan-digested venison, and to prove its efficacy for lowering blood pressure. In addition, the ACE inhibitory activity of farmed venison should be investigated further.

Author Contributions: Conceptualization, S.T., S.K. (Shinpei Kawarai), K.T., W.M., M.M., and R.S.; methodology, S.T., S.K. (Sakurako Kaneko), K.S., A.M.A., and H.E.; validation, S.T., A.M.A., and H.E..; formal analysis, S.T., S.K. (Sakurako Kaneko), K.S., and H.E.; investigation, S.T., S.K. (Shinpei Kawarai), K.T., and W.M.; resources, M.M. and R.S.; data curation, S.T. and R.S.; writing—original draft preparation, S.T., K.S., and A.M.A.; writing-review and editing, S.T., S.K. (Sakurako Kaneko), K.S., A.M.A., H.E., S.K. (Shinpei Kawarai), K.T., W.M., M.M., and R.S.; visualization, S.T. and S.K. (Sakurako Kaneko); supervision, S.T. and R.S.; project administration, S.T., M.M., and R.S. All authors have read and agreed to the published version of the manuscript.

Funding: This study was supported by the Ministry of Education, Culture, Sports, Science and Technology-Supported Program for the Private University Research Branding Project, (2016-2019), the Ito Foundation Research Grant (2017), and JSPS KAKENHI Grant-in-Aid for Young Scientists Number 18K13024 and Scientific Research (B) Number $19 \mathrm{H} 03109$.

Acknowledgments: We would like to thank Editage (www.editage.jp) for English language editing.

Conflicts of Interest: The authors declare no conflict of interest.

\section{References}

1. Hoffman, L.C.; Wiklund, E. Game and venison-meat for the modern consumer. Meat Sci. 2006, 74, 197-208. [CrossRef]

2. Hoffman, L.C. The yield and carcass chemical composition of impala (Aepyceros melampus), a Southern African antelope species. J. Sci. Food Agric. 2000, 80, 752-756. [CrossRef]

3. Viljoen, J.J. A comparison of the lipid components of springbok meat with those of beef and the related importance on aspects of health. S. Afr. J. Sci. Technol. 1999, 18, 51-53.

4. Razmaitè, V.; Pileckas, V.; Šiukščius, A.; Juškienè, V. Fatty Acid Composition of Meat and Edible Offal from Free-Living Red Deer (Cervus elaphus). Foods 2020, 9, 923. [CrossRef] 
5. Utrilla, M.C.; García Ruiz, A.; Soriano, A. Effect of partial reduction of pork meat on the physicochemical and sensory quality of dry ripened sausages: Development of a healthy venison salchichon. Meat Sci. 2014, 98, 785-791. [CrossRef]

6. Cawthorn, D.M.; Fitzhenry, L.B.; Kotrba, R.; Bureš, D.; Hoffman, L.C. Chemical Composition of Wild Fallow Deer (Dama dama) Meat from South Africa: A Preliminary Evaluation. Foods 2020, 9, 598. [CrossRef]

7. Kudrnáčová, E.; Bartoň, L.; Bureš, D.; Hoffman, L.C. Carcass and meat characteristics from farm-raised and wild fallow deer (Dama dama) and red deer (Cervus elaphus): A review. Meat Sci. 2018, 141, 9-27. [CrossRef]

8. Hassan, A.A.; Sandanger, T.M.; Brustad, M. Selected vitamins and essential elements in meat from semi-domesticated reindeer (Rangifer tarandus L.) in mid- and northern Norway: Geographical variations and effect of animal population density. Nutrients 2012, 4, 724-739. [CrossRef]

9. Hassan, A.A.; Sandanger, T.M.; Brustad, M. Level of selected nutrients in meat, liver, tallow and bone marrow from semi-domesticated reindeer (Rangifer t. tarandus L.). Int. J. Circumpolar Health 2012, 71, 17997. [CrossRef]

10. Nilsson, M.L. Food, Nutrition, and Health in Sápmi. In Nutritional and Health Aspects of Food in Nordic Countries; Andersen, V., Bar, E., Wirtanen, G., Eds.; Academic Press: Cambrige, MA, USA, 2018; pp. 179-195.

11. Rincker, P.J.; Bechtel, P.J.; Finstadt, G.; Van Buuren, R.G.C.; Killefer, J.; McKeith, F.K. Similarities and differences in composition and selected sensory attributes of reindeer, caribou and beef. J. Muscle Foods 2006, 17, 65-78. [CrossRef]

12. Arihara, K. Strategies for designing novel functional meat products. Meat Sci. 2006, 74, 219-229. [CrossRef] [PubMed]

13. Toldrá, F.; Reig, M. Innovations for healthier processed meats. Trends Food Sci. Technol. 2011, $22,517-522$. [CrossRef]

14. Ryan, J.T.; Ross, R.P.; Bolton, D.; Fitzgerald, G.F.; Stanton, C. Bioactive peptides from muscle sources: Meat and fish. Nutrients 2011, 3, 765-791. [CrossRef] [PubMed]

15. Gallego, M.; Mauri, L.; Concepción Aristoy, M.; Toldrá, F.; Mora, L. Antioxidant peptides profile in dry-cured ham as affected by gastrointestinal digestion. J. Funct. Foods 2020, 69, 103956. [CrossRef]

16. Simonetti, A.; Gambacorta, E.; Perna, A. Antioxidative and antihypertensive activities of pig meat before and after cooking and in vitro gastrointestinal digestion: Comparison between italian autochthonous pig suino nero lucano and a modern crossbred pig. Food Chem. 2016, 212, 590-595. [CrossRef]

17. Wang, L.; Li, X.; Li, Y.; Liu, W.; Jia, X.; Qiao, X.; Qu, C.; Cheng, X.; Wang, S. Antioxidant and angiotensin I-converting enzyme inhibitory activities of Xuanwei ham before and after cooking and in vitro simulated gastrointestinal digestion. R. Soc. Open Sci. 2018, 5, 180276. [CrossRef]

18. Ahhmed, A.M.; Muguruma, M. A review of meat protein hydrolysates and hypertension. Meat Sci. 2010, 86, 110-118. [CrossRef]

19. Hong, F.; Ming, L.; Yi, S.; Zhanxia, L.; Yongquan, W.; Chi, L. The antihypertensive effect of peptides: A novel alternative to drugs? Peptides 2008, 29, 1062-1071. [CrossRef]

20. Bah, C.S.; Carne, A.; McConnell, M.A.; Mros, S.; Bekhit, A.E.-D.A. Production of bioactive peptide hydrolysates from deer, sheep, pig and cattle red blood cell fractions using plant and fungal protease preparations. Food Chem. 2016, 202, 458-466. [CrossRef]

21. Kim, E.K.; Lee, S.J.; Jeon, B.T.; Moon, S.H.; Kim, B.; Park, T.K.; Han, J.-S.; Park, P.J. Purification and characterisation of antioxidative peptides from enzymatic hydrolysates of venison protein. Food Chem. 2009, 114, 1365-1370. [CrossRef]

22. Kim, E.K.; Lee, S.J.; Moon, S.H.; Jeon, B.T.; Kim, B.; Park, T.K.; Han, J.-S.; Park, P.J. Neuroprotective effects of a novel peptide purified from venison protein. J. Microbiol. Biotechnol. 2010, 20, 700-707. [CrossRef] [PubMed]

23. Storcksdieck, S.; Bonsmann, G.; Hurrell, R.F. Iron-Binding properties, amino acid composition, and structure of muscle tissue peptides from in vitro digestion of different meat sources. J. Food Sci. 2007, 72, S019-S029. [CrossRef] [PubMed]

24. Cushman, D.W.; Cheung, C.H. Spectrophotometric assay and properties of the angiotensin-converting enzyme of rabbit lung. Biochem. Pharmacol. 1971, 20, 1637-1648. [CrossRef]

25. Takeda, S.; Matsufuji, H.; Nakade, K.; Takenoyama, S.; Ahhmed, A.M.; Sakata, R.; Kawahara, S.; Muguruma, M. Investigation of lactic acid bacterial strains for meat fermentation and the product's antioxidant and angiotensin-I-converting-enzyme inhibitory activities. Anim. Sci. J. 2017, 88, 507-516. [CrossRef] 
26. Cheung, H.S.; Wang, F.L.; Ondetti, M.A.; Sabo, E.F.; Cushman, D.W. Binding of peptide substrates and inhibitors of angiotensin-converting enzyme. importance of the $\mathrm{COOH}$-terminal dipeptide sequence. J. Biol. Chem. 1980, 255, 401-407.

27. Terashima, M.; Baba, T.; Ikemoto, N.; Katayama, M.; Morimoto, T.; Matsumura, S. Novel angiotensin-converting enzyme (ACE) inhibitory peptides derived from boneless chicken leg meat. J. Agric. Food Chem. 2010, 58, 7432-7436. [CrossRef]

28. Maeda, H.; Kobayashi, K.; Watanabe, T.; Satoh, M.; Nomura, F.; Sogawa, K. Urinary carboxylesterase 5A fragment as an early diagnostic marker of cat chronic kidney disease. J. Electrophor. 2019, 63, 39-45. [CrossRef]

29. Sogawa, K.; Kodera, Y.; Satoh, M.; Kawashima, Y.; Umemura, H.; Maruyama, K.; Takizawa, H.; Yokosuka, O.; Nomura, F. Increased serum levels of pigment epithelium-derived factor by excessive alcohol consumption-detection and identification by a three-step serum proteome analysis. Alcohol. Clin. Exp. Res. 2011, 35, 211-217. [CrossRef]

30. Maeda, H.; Sogawa, K.; Sakaguchi, K.; Abe, S.; Sagizaka, W.; Mochizuki, S.; Horie, W.; Watanabe, T.; Shibata, Y.; Satoh, M.; et al. Urinary albumin and transferrin as early diagnostic markers of chronic kidney disease. J. Vet. Med. Sci. 2015, 77, 937-943. [CrossRef]

31. Sangsawad, P.; Roytrakul, S.; Yongsawatdigul, J. Angiotensin converting enzyme (ACE) inhibitory peptides derived from the simulated in vitro gastrointestinal digestion of cooked chicken breast. J. Funct. Foods 2017, 29, 77-83. [CrossRef]

32. Ahhmed, M.A.; Özer, N.; Özcan, C.; Çam, M.; Sağdic, O.; Arici, M.; Yilmaz, T.M.; Yetim, H.; Kim, J.; Muguruma, M.; et al. Solubility, stability and blood pressure lowering-properties of fresh and cured beef proteins. Acta Sci. Nutr. Health 2019, 3, 16-26.

33. Wen, S.; Zhou, G.; Song, S.; Xu, X.; Voglmeir, J.; Liu, L.; Zhao, F.; Li, M.; Li, L.; Yu, X.; et al. Discrimination of in vitro and in vivo digestion products of meat proteins from pork, beef, chicken, and fish. Proteomics 2015, 15, 3688-3698. [CrossRef] [PubMed]

34. Montowska, M.; Rao, W.; Alexander, M.R.; Tucker, G.A.; Barrett, D.A. Tryptic digestion coupled with ambient desorption electrospray ionization and liquid extraction surface analysis mass spectrometry enabling identification of skeletal muscle proteins in mixtures and distinguishing between beef, pork, horse, chicken, and turkey meat. Anal. Chem. 2014, 86, 4479-4487. [CrossRef] [PubMed]

35. Jensen, I.J.; Dort, J.; Eilertsen, K.E. Proximate composition, antihypertensive and antioxidative properties of the semimembranosus muscle from pork and beef after cooking and in vitro digestion. Meat Sci. 2014, 96, 916-921. [CrossRef] [PubMed]

36. Brodkorb, A.; Egger, L.; Alminger, M.; Alvito, P.; Assunção, R.; Balance, S.; Bohn, T.; Bourlieu-Lacanal, C.; Boutrou, R.; Carrière, F.; et al. INFOGEST static in vitro simulation of gastrointestinal food digestion. Nat. Protoc. 2019, 14, 991-1014. [CrossRef]

37. Paleari, M.A.; Moretti, V.M.; Beretta, G.; Mentasti, T.; Bersani, C. Cured products from different animal species. Meat Sci. 2003, 63, 485-489. [CrossRef]

38. Hou, W.C.; Chen, H.J.; Lin, Y.H. Antioxidant peptides with angiotensin converting enzyme inhibitory activities and applications for angiotensin converting enzyme purification. J. Agric. Food Chem. 2003, 51, 1706-1709. [CrossRef]

39. Marcolini, E.; Babini, E.; Bordoni, A.; Di Nunzio, M.; Laghi, L.; Maczó, A.; Picone, G.; Szerdahelyi, E.; Valli, V.; Capozzi, F. Bioaccessibility of the bioactive peptide carnosine during in vitro digestion of cured beef meat. J. Agric. Food Chem. 2015, 63, 4973-4978. [CrossRef]

40. Han, Y.; Gao, B.; Zhao, S.; Wang, M.; Jian, L.; Han, L.; Liu, X. Simultaneous detection of carnosine and anserine by UHPLC-MS/MS and its application on biomarker analysis for differentiation of meat and bone meal. Molecules 2019, 24, 217. [CrossRef]

41. Gil-Agustí, M.; Esteve-Romero, J.; Carda-Broch, S. Anserine and carnosine determination in meat samples by pure micellar liquid chromatography. J. Chromatogr. A 2008, 1189, 444-450. [CrossRef]

42. Chakrabarti, S.; Guha, S.; Majumder, K. Food-Derived bioactive peptides in human health: Challenges and opportunities. Nutrients 2018, 10, 1738. [CrossRef] [PubMed]

43. Sánchez, A.; Vazquez, A. Bioactive peptides: A review. Food Qual. Saf. 2017, 1, 29-46. [CrossRef] 
44. Jang, A.; Jo, C.; Kang, K.S.; Lee, M. Antimicrobial and human cancer cell cytotoxic effect of synthetic angiotensin-converting enzyme (ACE) inhibitory peptides. Food Chem. 2008, 107, 327-336. [CrossRef]

45. Katayama, K.; Fuchu, H.; Sugiyama, M.; Kawahara, S.; Yamauchi, K.; Kawamura, Y.; Muguruma, M. Peptic hydrolysate of porcine crude myosin has many active fractions inhibiting angiotensin I-converting enzyme. Asian-australas. J. Anim. Sci. 2003, 16, 1384-1389. [CrossRef]

(C) 2020 by the authors. Licensee MDPI, Basel, Switzerland. This article is an open access article distributed under the terms and conditions of the Creative Commons Attribution (CC BY) license (http://creativecommons.org/licenses/by/4.0/). 